\title{
DIE GODSOPENBARING IN DIE NATUUR
}

\author{
W.J. Ouweneel \\ Departement Wetenskapsleer \\ Potchefstroomse Universiteit vir $\mathrm{CHO}$ \\ POTCHEFSTROOM
}

\begin{abstract}
In this article the theological term (creational) revelation is discussed in relation with the term divine law. The law itself is revelation. The significance of these terms for other scholarly disciplines, in particular for philosophy, is briefly discussed. Tradition distinguishes between general and special revelation. It is argued that any such distinction is necessarily founded in a cosmological view of creational reality. In this context, it is attempted to refute both the notions of natural and of supranatural theology. Some words on the relevant passage in Romans 1:20, 21 are added to this agument. Finally, the essential philosophical question is discussed whether, and in what way, science is oriented upon God's creational revelation. Both the negation of such a relationship and the overestimation of it are criticized.
\end{abstract}

\section{DIE GODSOPENBARING IN DIE NATUUR}

In hierdie artikel word kortliks enkele kanttekeninge geplaas by die term (skeppings)openbaring. Hierdie term hang nou saam met die term wet van God. Albei terme speel 'n belangrike rol binne die dogmatiek - baie belangriker as wat in hierdie artikel aan die orde kan kom, maar hulle betekenis reik ook verder as die teologie op grond van hulle groot belang vir die Christelike beoefening van die ander vakwetenskappe en van die filosofie. In hierdie artikel word 'n kort bespreking gewy aan die wysgerige implikasies van die term (skeppings)openbaring.

\subsection{Die verbinding tussen wet en openbaring}

In bykans elke bespreking van die wet van God en die kosmiese wetsorde kom die vraag op watter wyse ons hierdie wetsorde kan leer ken, vanself aan die orde. En in samehang met hierdie vraag sou ons ook graag wil weet of ons uit die kosmiese wetsorde self ook die Wetgewer sou kon leer ken. Dit is inderdaad in beginsel moontlik deurdat ons in die kosmiese wetsorde met goddelike openbaring te doen het. Hierin lê die verband tussen die twee begrippe wat hier ondersoek word: in die wets- of skeppingsorde openbaar God Homself (of miskien beter: 'iets' van Homself). Hierdie aspek van God se Selfopenbaring in die wetsorde verdien nadere aandag. 
Dit is opmerklik dat die Hebreeuse woord nרוֹ self soms 'openbaring' beteken. Die woord nררה kom waarskynlik van die werkwoord רדר, 'om te leer, onderwys', en beteken dus oorspronklik 'leer, onderwysing', en soms ook 'onthulling, openbaring'. Hierdie betekenisnuanse kom duidelik tot uitdrukking in die boek Jesaja: in die 1983vertaling word die woord nר nertaal met 'openbaring' in Jesaja 2:3 ("... uit Sion kom die openbaring, uit Jerusalem die woord van die Here") en 5:24 ("... hulle het hulle nie gesteur aan die openbaring van die Here die Almagtige nie"). In ander Jesaja-tekste soos 1:10 (leer); 42:4 (leer) en 21 (woord); 51:4 (onderrig) en 7 (wet) het eweneens die ruim betekenis van die openbaring van God se wil. Dit is veral duidelik waar dit gaan om God se openbaring aan alle volke: $2: 2-4 ; 42: 3-7 ; 51: 4-9$.

Eintlik is die Godsopenbaring altyd onthulling van God se wil, hetsy sy Skepperswil of sy Verlosserswil, soos ook die wet onthulling van God se wil is. Hierin lê weer die verbinding tussen wet en openbaring. In Psalm 19 is daar net een openbaring van God: of die openbaring nou geld vir die wetsorde in die natuur en of dit betrekking het op die geëksplisiteerde wet vir die mens se lewe, dit is net een wet, dit wil sê een openbaring.

In die Tien Woorde het ons met die 'wet van God', maar ook ewe duidelik met die 'openbaring van God' te doen, soos blyk uit twee dinge: (a) die aanhef (dikwels as die eerste van die Tien Woorde beskou!), waarin God Homself bekendstel, openbaar, deur te sê Wie Hy is: "Ek is die Here jou God wat jou uit Egipte, uit die plek van die slawerny, bevry het" (Eks. 20:2); (b) uit die aard van die wet, wat die mens oproep tot ' $n$ heiligheid wat allereers in God Self openbaar geword het: "... wees heilig, want Ek is heilig" (Lev. 11:44; 19:2; 20:7 e.v.; 1 Pet. 1:16).

Die openbaring van God het 'n groot reikwydte. God openbaar Homself in die natuur, in sy skeppingswoord en in sy onderhoudingswoord (Rom. 1:19 e.v.), Hy openbaar Homself ook in die Verlossingswoord (Rom. 3:21 e.v.; 2 Tim. 1:9 e.v.), die vleesgeworde Woord - Christus (Matt. 16:17; Joh. 2:11; 1 Tim. 3:16; Heb. 9:26; 1 Pet. 1:20; 1 Joh. 3:5,8), die Skrifgeworde Woord (1 Kor. 2:10-13; Ef. 3:5; 2 Tim. 3:16; 2 Pet. 1:20 e.v.) en die verkondigde Woord (Kol. 4:4; 1 Tess. 2:13) (vgl. Heyns, 1978: 146 e.v.).

God openbaar Homself nie slegs in die wetsy van die geskape werklikheid nie, maar ook in die wetmatige oftewel die feitelike of subjeksy. Dit kom tot uiting in sowel die natuur as die geskiedenis en die kultuur in algemene sin:

* In elke wonderwerk van die natuur kom ons te staan voor God se skeppingsopenbaring. Ons aanskou sy majesteit in die grootsheid van die hemelliggame (Ps. 19:1-7) en sy trou in hulle bestendigheid (Ps. 89:3-6, 29 e.v., 37 e.v.), ons hoor Hom 
in die stem van die donder (Ps. 29), ons sien sy mag in die berge en bosse, in die plante- en dierewêreld (Ps. 104; 147).

- In verband met die geskiedenis betoog Dengerink (1986:226) dat die 'werklikheidsgebeure' konstant is, dog nie staties of star nie, maar wel dinamies. Sowel die subjeksy as die wetsy

\begin{abstract}
is opgenomen in de dynamiek van het werkelijkheidsgebeuren en komt in de dynamiek tot verdere ontsluiting. Zo verstaan, kan worden gesproken van een voortgaande openbaring van datgene, wat er in het woord van schepping en herschepping ligt besloten. Onzekerheden, die er in een bepaalde fase van de geschiedenis door nieuwe ontwikkelingen kunnen ontstaan, worden later dikwijls als schijnzekerheden ontmaskerd, zij het dat ook het omgekeerde kan gebeuren. Die werkelijkbeid is in haar scheppingsmatige eenheid en betrouwbaarheid juist krachtens het scheppende en herscheppende woord van de levende God voortdurend in beweging.
\end{abstract}

In die geskiedenis het ons met die handelinge van die mens te doen, met al sy foute, onsekerhede en veranderlikheid, maar die geskiedenis is $60 \mathrm{k} \mathrm{God} \mathrm{se} \mathrm{hande-}$ linge, en is as sodanig openbaring van God. Die gedagte van die 'voortgaande openbaring' (kyk sitaat) is daarby baie belangrik. Dit sien ons duidelik in die heilsgeskiedenis (bv. Eks. 6:2; Rom. 16:25 e.v.; 1 Kor. 2:6-10; Ef. 3:4-6; Heb. 1:1 e.v.; 1 Pet. 1:10-12), maar die héle geskiedenis is 'heilsgeskiedenis'. Hoe moeilik dit ook al mag wees om die geskiedenis te interpreteer, is die geskiedenis 'n openbaring van God wat, 'sigbaar' vir die gelowige wat God se 'hand' in die geskiedenis opmerk, heenreik na die geskiedenis se voleinding in Christus.

- God openbaar Homself ook in die kultuurprodukte. Ook in hierdie skildery of in daardie motor bewonder ons God se skeppingsmag, want dit gaan hier om kultuurskeppinge, soos Smit (1980:177) dit stel: "... gemaak deur die mens wat God geskep het met die vermoë om die skeppingswette te kan ontdek en beheers". God openbaar Homself enersyds in die wet wat Hy vir sy skepsels ingestel het, en andersyds in die skepsel wat Hy onder sy wet gestel het en in dit wat hierdie skepsel self weer skep. Kultuur is die mens se skeppende ontsluiting van die natuur, in opdrag van God, en daarmee 'n voortgaande ontsluiting van die Godsopenbaring in die natuur. Op grond hiervan kan ' $n$ mens dus selfs in die kultuur miskien van ' $n$ 'voortgaande openbaring' praat. Die natuur se ontsluiting impliseer die ontdekking van nuwe aspekte van die natuur, waardeur ook nuwe aspekte van God se ewige krag en goddelikheid sigbaar word. 


\section{Die tweèrlei openbaring van God}

Deur die geloof weet en bely ons dat God die wêreld geskep het, en dat hierdie Skepper-God Hom in sy geskape werke openbaar aan die mens. Die hemel getuig van die mag van God, die uitspansel maak die werk van sy hande bekend (Ps. 19:1). God se ewigdurende krag en sy goddelikheid word uit sy werke duidelik afgelei (Rom. 1:20). Ons het kennis van hierdie Selfopenbaring van God in sy werke - soos ook uit hierdie paar verse reeds implisiet blyk - deur sy Selfopenbaring in die Skrif, die op skrif gestelde Woord van God. Anders gesê: deur hierdie woordopenbaring van God het ons kennis van die werkopenbaring van God.

Wanneer die teologie (as wetenskap skerp te onderskei - maar nie te skei nie - van die so pas geformuleerde geloofsbelydenis) hom teoreties rekenskap probeer gee van die logiese onderskeidings wat in hierdie geloofsbelydenis voorhande is, word die saak meer verwikkeld. Sedert die Apologete het die teologie al 'n onderskeid gemaak tussen die tweërlei openbaring:

- Die algemene openbaring (revelatio universalis), wat gerig is tot die mens en die mensheid oor die algemeen, ook soms die natuurlike of middellike openbaring genoem, omdat hierdie openbaring gesien word as iets wat vanself, natuurlikerwys, asook indirek (sonder woord van God) plaasvind. Daarom vind ons ook spore van die algemene openbaring in alle godsdienste. Hierdie openbaring vind ons vergestalt in die natuur, nie net die uitwendige natuur nie, maar ook die inwendige natuur van die mens en die geskiedenis van die mensheid, wat dus ook die kultuur omvat (1.1). Hierdie openbaring word daarom ook skeppingsopenbaring genoem, omdat dit nie slegs om die selfopenbaring van God in die eintlike skeppingswerk gaan nie, maar ook om sy selfopenbaring in die werk van die onderhouding; vandaar ook die term werkopenbaring.

* Die besondere openbaring (revelatio particularis), wat gerig is tot Israel en die Christene in die besonder, ook soms die bo-natuurlike of onmiddellike openbaring genoem, omdat dit op 'n besondere, regstreekse wyse plaasvind deur die wonder van die inspirasie. Hierdie openbaring vind ons ook uitgedruk in die Skrif, sodat sommige mense ook praat van woordopenbaring.

Dit is nie die bedoeling om hier uitvoerig op alle aspekte van die diskussie rondom hierdie tweërlei openbaring in te gaan nie, 'n diskussie wat in die 20 ste eeu nog baie lewendiger geword het as gevolg van onder andere skerp kritiek op die konsep van die algemene openbaring. ${ }^{1}$ Dit gaan tans egter veral om die wysgerige relevansie van die 
teologiese diskussie. Omdat die teologie as vakwetenskap noodwendig sy eie vakfilosofie het, wortel die teologiese diskussie in die tweërlei Godsopenbaring en noodwendig in die wysgerig-kosmologiese v6órvrae. Elke wetenskaplike diskussie oor die skeppingsopenbaring veronderstel (implisiet of eksplisiet) 'n kosmologiese perspektief op die skeppingswerklikheid. Hoe 'Skriftuurlik' 'n teologiese beskouing oor die skeppingsopenbaring ook mag lyk, dit kan ongelukkig al te maklik wortel in 'n (deels) heidense kosmologie. Juis waar die teologie onvoldoende bewus is van sy kosmologiese voorvrae val die teologie te maklik in die valstrik dat sy skeppingsbeskouing gekleur is deur heidens-kosmologiese denke.

Die allerbelangrikste aspekte van sulke heidense invloede wat die teologiese navorsing omtrent die Godsopenbaring belas, stam uit die skolastiese dualisme van 'natuur' en 'genade' (of 'bo-natuur') (vgl. ook die diskussie daaroor by Troost, 1978). Die algemene openbaring behoort dan tot die 'onderverdieping' van die natuur, die terrein van God se middellike handeling, en die besondere openbaring behoort tot die "boverdieping' van die genade, die terrein van God se on-middellike handeling. Hierdie dualisme het vaste beslag gekry in die Rooms-Katolieke teologie en filosofie sedert Thomas van Aquino en die amptelike aanvaarding van sy denke deur die RoomsKatolieke kerk. In die Protestantse teologie het hierdie skolastiese denkskema egter ook amper vanaf die begin 'n vastrapplek gekry.

Dikwels was teoloë hulle van hierdie dualisme baie goed bewus gewees, en dikwels het hulle hul daarvan probeer losmaak. So het hulle menigmaal die natuur laat probeer opgaan in die genade (in hierdie eeu veral by Karl Barth), of omgekeerd die genade laat opgaan in die natuur (so algemeen onder vrysinnige teoloë). Gewoonlik veronderstel hierdie (vrugtelose) pogings steeds die natuur/genade-denkskema, kom nie los daarvan of oorstyg dit nie, deurdat sodanige pogings nie uitgaan van 'n radikaal Christelik-wysgerige werklikheidsbeskouing nie.

'n Dergelike beskouing hou baie meer in as om slegs vaagweg blyke te gee van 'n 'harmonie' tussen natuur en genade of oor 'harmonie' in die Skrif se getuienis oor algemene en besondere openbaring (vgl. Berkouwer, 1951:261). Troosi (1978:107) wys op die syns insiens onsekere manier waarop Berkouwer daarna verwys wanneer hy die een keer sê dat woord- en werkopenbaring nie in die geskiedenis van God se handeling geskei word nie en die ander keer dat hulle wel 'uiteenval' (vgl. ook Troost, 1978:121

\footnotetext{
${ }^{1}$ Kyk daaroor bywoorbeeld slandaardwerke soos dié van Bavinck (1928), dl.l, veral hfst. 10-13, veral Berkouwer (1951), maar ook 'n meer resente werk soos Vander Stelt (1978) en Heyns (1978:7-11).
} 
asook Berkouwer, 1951:254,258). Berkouwer (1951:254) wys weliswaar tereg daarop dat ' $n$ mens nie teologies na ' $n$ eenheid in God se openbaringshandeling moet soek nie deurdat 'n mens "boven het geloof uit grijpt naar een doorzichtige rationele synthese". Daarmee is egter nog nie gesê dat geen enkele sintese ten aansien van die Godsopenbaring moontlik is nie as 'n mens hierdie sintese nie primêr soek op die rasionele vlak en/of vertolk as 'n sintese wat 'bo die geloof' (in watter betekenis ook a) uitstyg nie. Wat teologies onderskei word as woord- en werkopenbaring, sou wel deeglik sy eenheid kon vind - nie bó 'die geloof nie, maar - ín die geloof in die sentraal-religieuse sin van die woord. Dit is die bo-tydelike geloof wat die rasionaliteit - as een van die tydelike funksies van die bo-tydelike gelowige hart - en daarmee ook alle teologiese problematiek oorstyg. Hierdie gedagte sal in die volgende paragrawe breër uitgewerk word.

\section{NATUURLIKE EN BO-NATUURUIKE TEOLOGIE}

\subsection{Die natuurlike teologie}

Vir die juiste verstaan van die aard van die werkopenbarlng en sy verhouding tot die woordopenbaring is dit van die grootste belang om die genoemde verhouding tussen die sentraal-religieuse geloof en die temporeel-funksionele rasionaliteit op die juiste wyse te verstaan. Alleen dit kan ons verhoed om te verval in die gevaar van een of ander nutuurlike teologie (vgl. Berkouwer 1951:hfst.4). Soos bekend, is dit 'n teologie wat - so meen die aanhangers daarvan - wetenskaplik aan elke denkende mens bewys kan word en wat dus aansluit by die mens se 'natuur' (lees: se outonome rede) en nie die ('bo-natuurlike') geloof vooronderstel nie. Op hierdie wyse trag hierdie teologie om op grond van die algemene openbaring die bestaan van God met suiwer rasionele argumente aan te toon.

Die natuurlike teologie is in sy geheel verweef met die skolastiese onderskeiding tussen natuur en genade en het dan ook sy invloedrykste voorvegter in Thomas van Aquino gevind. Volgens Thomas besit die menslike rede op die terrein van die 'natuur' 'n betreklike outonomie. By die sondeval het die mens sy verstand byna ongeskonde bewaar, waardeur die rede volgens sy eie lig in staat is om die 'natuurlike waarhede' uit die algemene openbaring af te lees. Die rede is eie aan gelowiges én ongelowiges, op grond waarvan hulle selfs gesamentlik kan redeneer en die 'natuurlike' of sekulêre sfeer kan deurgrond, of selfs byvoorbeeld kan aantoon dat daar 'n God is. Hierdie 'natuurlike teologie' kan dus kragtens die gemeenskaplike rede deur alle mense gesamentlik bedryf word. Die rede kan egter die bo-natuurlike waarhede nie bewys nie 
(byvoorbeeld wat God is, die Drie-eenheid, die inkarnasie, die opstanding, die verlossing, die laaste oordeel). Die rede is hoogstens in staat om argumente téen hierdie waarhede te weerlê. Die 'natuurlike' teologie bly dus agter by die 'bonatuurlike' teologie. Die eerste is slegs 'n praeambula fidei ('voorportaal van die geloof). Op die terrein van die 'genade' is die rede nie uitgeskakel nie - die bonatuurlike genade hef die natuur nooit op nie - maar is volstrek afhanklik van die besondere openbaring en van geloof ('n donum supperadditum van God, dus 'bonatuurlik'), wat nodig is om die bo-natuurlike of sakrale sfeer te deurvors. Waar die sakrale sfeer die sekulêre sfeer ver te bowe gaan, mag die sekulêre sfeer met sy natuurlike teologie egter tog nie geminag word nie, want ook hierin gaan dit om 'openbaring van God'. Die reformatoriese denke wys egter die geïmpliseerde skeiding tussen natuur en genade (en derhalwe ook tussen rede en geloof, tussen natuurwetenskap en teologie, ensovoorts) af as geheel onbybels. Die reformatoriese denke neem standpunt in teen die skolastiek en stel dat die menslike rede nie outonoom is nie, maar dat alle (ware of valse) verstand wortel in (ware of valse) religie. Thomas se ontkenning van die algehele verdorwenheid van die natuurlike verstand (vgl. Ef. 4:17) beteken 'n ontkenning van die volledige sondeval. 'n Deur die sonde verduisterde verstand is nie in staat om, onafhanklik van geloof of religie, deur suiwer rasionele argumente, die bestaan van God uit die algemene openbaring aan te toon nie. David Hume en Immanuel Kant het dan ook beslissend - al was dit nie op grond van Bybelse motiewe nie - met Thomas se sogenaamde 'Godsbewyse' afgereken. Die treurige gevolg hiervan was dat baie mense die konklusie getrek het dat as die Godsbewyse nie deug nie, God dan ook nie bestaan nie. Die Christen het egter baie ander 'gronde' om in God te glo: Le coeur a ses propres raisons, que la raison ne connaît pas, soos Pascal reeds opgemerk het in sy Pensées. Die geloof is nie primêr 'n saak van die verstand nie, maar van die (bo-tydelike) hart, waarvan die verstand slegs een van die (tydelike) funksies is.

\section{Die bo-natuurlike teologie}

Omdat die onderskeid tussen natuur en bo-natuur afgewys word, moet dit origens duidelik wees dat dit slegs konsekwent is as nie net die natuurlike teologie afgewys word nie, maar ook die daardeur geïmpliseerde bo-natuurlike teologie. Reste van die skolastiese idee van 'n bo-natuurlike teologie word ook dikwels gevind in die reformatoriese tradisie, onder andere in die uitdrukking 'heilige godgeleerdheid', soos in die titel van Kuyper se bekende Ensiklopedie (1908/09). God is heilig en God se Woord is heilig; maar die teologie, as feilbare, gebrekkige mensewerk, is net so baie of min heilig as die ekonomie of die chemie. 
Wanneer gepraat word van 'n 'heilige' teologie hang dit nou saam met idees omtrent die (vermeende) studie-objek van die teologie. Selfs as dit korrek sou wees om te sê dat hierdie studie-objek die Heilige Skrif sou wees, sou die teologie nie 'heilig' wees nie - maar die siening dat die Bybel die studie-objek van die teologie is, is al op sigself 'n skolastiese siening (vgl. Strauss, 1988:137,138,152). Die teologie word dan beskou as die wetenskap van die 'bo-verdieping' van die genade (waartoe die Skrif behoort) en die ander vakwetenskappe met die filosofie behoort dan tot die 'onderverdieping' van die natuur. Die ('heilige') teologie bestudeer die woordopenbaring, terwyl die ander ('onheilige') vakwetenskappe 'slegs' die werkopenbaring bestudeer (vgl. Heyns \& Jonker, 1977:55, 62, 75: die teologie is met die God van die wêreld besig en die ander wetenskappe met die wêreld van God; die voorwerp van die teologie is die Skrif en dié van die natuurwetenskappe is die natuur).

Hier word myns insiens 'n dubbele fout gemaak. Ten eerste het ons hier met dieselfde natuur/genade-dualistiese grondfout te doen, en ten tweede is dit 'n verkeerde opvatting om te dink dat énige wetenskap 'n bepaalde entiteit of klas van entiteite bestudeer. Vakwetenskappe bestudeer streng genome nie entiteite nie, maar altyd die hele werklikheid, maar dan vanuit een bepaalde modale gesigspunt (vgl. Strauss, 1978:2, 3; vgl. ook König, 1982:26, hoewel hy dit wysgerig swakker uitdruk). So bestudeer die teologie nie (net) die Skrif nie, maar die hele werklikheid (skeppingsopenbaring!), al is dit vanuit die een gesigspunt van die modale geloofsaspek. Dit geld vir sowel die bestudering van die Skrif, wat deur die teologie slegs vanuit sy geloofsaspek bestudeer word, as vir die bestudering van ander dele van die werklikheid: dink hier aan die kerkreg, kerkgeskiedenis, godsdiensfenomenologie, homiletiek, ensovoorts, waarin steeds ander fasette van die werklikheid vanuit die geloofsgesigspunt belig word.

Op presies dieselfde wyse bestudeer die ander vakwetenskappe ook die hele werklikheid, maar elk vanuit hulle eie modale gesigspunt: die fisika vanuit die energetiese, die biologie vanuit die organiese, die logika vanuit die analitiese, die regswetenskap vanuit die juridiese gesigspunt, ensovoorts. Die teologie en die ander vakwetenskappe bestudeer nie verskillende 'dele' van die werklikheid nie, naamlik die 'bo-natuur' of die 'natuur' nie, maar hulle bestudeer dieselfde totale skeppingswerklikheid - en daarmee dieselfde Godsopenbaring! - al is dit steeds vanuit verskillende modale gesigspunte. Daar is net een werklikheid, en net een openbaring.

Soos die teologie ook die werklikheid buite die Skrif bestudeer, so bestudeer ander (gelowige) vakwetenskaplikes ook die Skrif. Immers, ook die Bybel as skeppingswerk van God behoort tot die skeppingswerklikheid (4.1), en daarom kan (en moet) die 
Skrif ook in elke vakwetenskap betrek word, sonder om enige vakwetenskap daarmee in teologie te verander. Soos die teoloog die Skrif bestudeer bloot vanuit die modale geloofsgesigspunt, so bestudeer die (gelowige) psigoloog die Skrif vanuit die psigiese, die historikus vanuit die histories-formatiewe, die ekonoom vanuit die ekonomiese gesigspunt, die juris vanuit die regsgesigspunt, die etikus vanuit die morele gesigspunt, ensovoorts. So sal byvoorbeeld die ekonoom die wet van Moses kan bestudeer in verband met sy groot ekonomiese betekenis, die juris is geïnteresseer in die juridiese betekenis, die sosioloog in die sosiale betekenis, en die teoloog in die godsdienstige (verbondsmatige) betekenis van die wet.

Elke gelowige wetenskaplike sal dus by geleentheid met vrug gebruik kan maak van Bybelse insigte en beginsels, sonder om daarmee sy vakgebied 'heilig' of 'bo-natuurlik' te maak. Die Skrif is nie die eksklusiewe terrein van die teologie nie, soos 'die natuur' en 'die kultuur' nie die eksklusiewe terreine van die natuur- of die geesteswetenskappe is nie. Ook hier is geen plek vir enige dualistiese siening nie. Dit sal duideliker word as in 4.1 nader ingegaan word op die verhouding tussen die woord- en die werkopenbaring.

\section{ROMEINE 1:20 e.v.}

In elke diskussie oor die skeppingsopenbaring (wat onmiskenbaar volgens die Skrif bestaan) en die natuurlike teologie (wat die reformatoriese denke radikaal van die hand wys) kom Romeine 1:20 e.v. noodwendig aan die orde, waar Paulus sê: "Van die skepping van die wêreld af kan 'n mens uit die werke van God duidelik aflei dat sy krag ewigdurend is en dat Hy waarlik God is, hoewel dit dinge is wat 'n mens nie met die oog kan sien nie. Vir hierdie mense is daar dus geen verontskuldiging nie, omdat al weet hulle van God, hulle Hom nie as God eer en dank nie."

Oor hierdie teks is al baie boeke vol geskryf, sodat ons ons moet beperk tot enkele punte wat vir die diskussie relevant is. Menigeen wou hierdie teks as 'n onloënbare bewysplaas vir 'n natuurlike teologie sien, maar hiervoor bestaan geen genoegsame gronde nie (vgl. die diskussie by Berkouwer, 1951, veral hfst. VII en X). Romeine 1 leer nie dat die mens met behulp van die natuurlike rede die bestaan van God uit sy skeppingswerke kan aflei nie. Inteendeel, hierdie hoofstuk spreek so duidelik en radikaal oor die mens se verdorwenheid en God se toorn daaroor (vgl. vs. 18 e.v.) dat ons op geen wyse hier grond kan vind vir die aanname van 'n outonome, dit wil sê nie deur die sonde verdorwe en onafhanklik van die hart of die geloof funksionerende rede 
nie. Die mens wat hier inderdaad 'kennis' het van God (e.v. 21), het dit nie danksy die 'natuurlike lig van die rede' nie, maar besit hierdie kennis juis in die grootste dwaasheid (e.v. 22). Die beeld wat die heiden hier van God het, is nie dié van die skolastiese 'eerste oorsaak' of 'onbeweegde beweger' nie, maar die beeld 'wat lyk soos 'n verganklike mens of soos voëls of diere of slange' (e.v. 23). Hoe moet daar in hierdie Skrifgedeelte dan 'n grond gevind word vir' $n$ natuurlike teologie? In Romeine 1 is inderdaad implisiet sprake van 'n skeppingsopenbaring, maar juis nie van 'n natuurlike teologie nie, maar van 'n mensheid wat weliswaar aan die duidelike bewys van die skeppingsopenbaring nie kan ontkom nie, maar slegs daarop kan reageer met afgodery. Dit is nie die werksaamheid van die 'natuurlike rede' nie, maar van die verdorwe hart - Hier is inderdaad sprake van 'n 'duidelik aflei', wat die verstand impliseer (die teks spreek van die voûs: denke, gemoed), maar uit die hele samehang van hierdie hoofstuk blyk wat 'n verdorwe verstand dit is. Die skeppingsopenbaring het vir die natuurlike mens inderdaad te sterk geword, hy kan nie om God se ewige krag en goddelikheid heen nie, maar in die verdorwenheid van sy hart - 'n verdorwenheid wat deurwerk in alle funksies van die hart, ook die verstands- en die geloofsfunksie - kan hy slegs daarop reageer deur hierdie 'kennis' van God te verwerklik in die bou van 'af-gode': skyngode wat hom slegs van die ware God 'af-voer'.

Romeine 1:20 sê trouens ook nie dat 'n mens God se bestaan nie, maar wel sy ewigdurende krag en dat Hy waarlik God is, uit sy werke aflei (1933-vertaling: sy goddelikheid; $\theta \in$ totns). Hierin word sy bestaan reeds veronderstel. Vanuit sy 'natuurlike Godskennis', of, soos Calvyn dit noem, sy sensus divinitatis of semen religionis (Heyns,1978:52 e.v.) - in soverre ons nog hierdie deur die natuurlike teologie belaste terme kan gebruik ${ }^{2}$ - 'weet' die mens in die diepte van sy hart van God se bestaan en erken hy vanuit hierdie besef van sy werke God se ewige krag en goddelikheid. Vervolgens word hierdie kennis egter gemanifesteer in alle verwording van die heidendom met sy veelvuldige vorms van afgodery. In soverre ons van 'n sensus divinitatis praat, is dit geen outonoom-rasionele (nie deur die sonde aangetaste) 'orgaan' van die kennis van God nie, maar slegs 'n onontkombare 'indruk', wat deur die indringendheid van die skeppingsopenbaring by die mens in sy hart opgewek word. Nie die argumentasie van een of ander natuurlike teologie nie, maar juis die afgodery wat in die wêreld bestaan, lewer die bewys van 'n sekere besef van Godheid, 'n sekere kiem van godsdiens. ${ }^{3}$

\footnotetext{
2 Jonker (s.j.:36,41) wil hier dan ook nie van natuurlike Godskennis praat nie; vergelyk wat hy sé oor die mens se gewete in verband met die algemene openbaring $(48,49)$.

${ }^{3}$ Aldus Calvyn in sy Institusie, 1.3 .1 ; vgl. 1.3 .3 en 1.4 .1 ; vgl. Heyns (1978:52-54).
} 
Dit is van groot belang om hier sorgvuldig te onderskei. So dikwels word die idee van 'n algemene openbaring onlosmaaklik gekoppel aan die natuurlike teologie, asof die een noodwendig die ander impliseer. Dit het sowel die voorstanders van die natuurlike teologie (soos die Rooms-Katolieke teoloë) as bepaalde teenstanders daarvan gedoen, waarvan laasgenoemde nie net die natuurlike teologie nie, maar tewens die idee van 'n algemene openbaring wou afwys, soos Karl Barth (Berkouwer, 1951:hfst.II; Heyns, 1978:14, 15). Die reformatoriese wysbegeerte hou egter enersyds vas aan die Bybelse idee van die algemene of werk- of skeppingsopenbaring, en wys andersyds ewe radikaal elke vorm van natuurlike teologie af.

Dit het as belangrike konsekwensie dat volgens hierdie standpunt die algemene openbaring dan ook pas werklik geken en verstaan kan word as die rede wat deur die wedergeboorte vernuwe en deur die krag van die Heilige Gees verlig is hom laat lei deur die lig wat vanuit die woordopenbaring op die werkopenbaring val (meer korrek: vanuit die Skrif op die res van die skeppingsopenbaring). Pas dan word die algemene openbaring ten volle as openbaring herken, en word sy reikwydte en betekenis verstaan in die lig van Christus, die geïnkarneerde Woord van God, wat ons ken uit die op skrif gestelde Woord van God. Slegs in die Skrif het ons die onmiskenbare getuienis omtrent God se bestaan én wese. Eers dáár val die volle lig op God as Wetgewer, en daarmee op die wetsorde waarin die skeppingswerklikheid gegrond is. Ware kennis (in die volle betekenis van hierdie term) van die kosmiese wetsorde is slegs moontlik vanuit 'n nuutgemaakte hart en by die lig van God se Woord.

In hierdie verband wys Heyns (1978:8) dan ook tereg daarop dat dit van die grootste betekenis is dat die sogenaamde natuurpsalms (Ps.8, 19, 29, 93, 104) die lofsange van Israel is wal hicr gehoor word. Die oe, wat God sien handel in die natuur, is
die oe wat deur die geloof geopen is, en die kennis van God wat hier tot uiting kom, is die kennis
van die hart wat deur die heil van die Here verlig is. Die ervaring van Gods genade binne die
ruimte van die verbond lei ook tot die bewuswording van Gods majesteit en heerlikheid in die
werke van sy hande.

\section{WETENSKAP EN WERKOPENBARING}

\subsection{Wetenskap gerig op die werkopenbaring?}

Een van die sentrale vrae wat in die verskillende vakfilosofieë aan die orde kom, is of, en in watter sin, die vakwetenskappe (die teologie ingesluit) en die filosofie gerig is op die wetsorde soos God dit vir die skeppingswerklikheid ingestel het. Skerper gestel: is 
die vakwetenskappe en die filosofie gerig op die skeppingsopenbaring as openbaring? Nog skerper gestel: lewer byvoorbeeld die natuurwetenskap ware (al is dit natuurlik altyd onvolledige) kennis van God op deur die kennis van die natuur, wat immers 'openbaring' van God is? Berkouwer (1951:237-239) het op hierdie vrae met 'n duidelike nee geantwoord:

\begin{abstract}
Men ging (...) de Heilige Schrift zien als het boek van de bijzondere Openbaring Gods en de natuur (...) als het boek van de algemene Openbaring. Zowel de theologie als de natuurwetenschap zouden zich dan met de Openbaring Gods bezighouden, de theologie met de bijzondere en de natuurwetenschap met de algemene Openbaring. (...) De consequentie hiervan is dan deze, dat wij de kennis van Gods Openbaring in de natuur in hoofdzaak te danken hebben aan de natuurwetenschap (...) Hierbij komt echter geheel op de achtergrond, dat het niet aangaat de kennis der natuur zonder meer gelijk te stellen met de kennis van Gods algemene Openbaring, want in die Openbaring gaat het om kennis van God Zelf. Daarom is het o.i. onjuist om te zeggen, wat meermalen geschiedt, dat de natuurwetenschap Gods algemene Openbaring 'onderzoekt' en zeker is bet eveneens onjuist om te zeggen, dat wij de kennis van Gods Openbaring in de natuur in boofdzaak danken aan de natuurwetenschap. Het komt ons voor, dat we hier met een vervlakking van het begrip en de werkelijkheid der Openbaring to doen hebben, al is dit allerminst bedoeld en al erkennen we ten volle, dat het onze rocping is de werken van Gods handelen met eerbied te onderzoeken. Maar in de Openbaring (Gods in die werken gaat het om Gods Zelfopenbaring en zij wordt niet eerst door natuurwctenschappelijk onderzoek gevonden, maar door het geloof, zoals dat reeds in de psalmen van Isrä̈! Joorklinkt. (...) In de z.g. naturussalmen gaat het dan ook niet om het begrip 'natuur' van de naturwetenschap, maar om cen visie des geloofs op de werken Zijner handen. Daarom handelen de natuurpsalmen ook nimmer over abstracte natuurzijden der kosmische werkelijkheid, maar om de - in de goede zin des woords - naieve werkelijkheid.
\end{abstract}

Hierdie lang sitaat gee uitstekend weer watter problematiek aan die orde kom by 'n diskussie oor die betrokke wees al dan nie van die wetenskap op die skeppingswerklikheid. In besonder blyk uit hierdie sitaat dat menige teologiese beskouing mank gaan deurdat dit nie gegrond is in 'n Christelik-wysgerige werklikheids- en wetenskapsbeskouing nie.

Berkouwer is ongetwyfeld reg dat natuurwetenskaplike navorsing as sodanig vir ons geen kennis van God oplewer nie en weliswaar gerig is op die 'natuur', maar daarmee nog nie regstreeks gerig is op die algemene Godsopenbaring in die natuur nie. Maar, vra Troost (1978:118) tereg:

Heft Berkouwer hier niet de dieptedimensie van alle kennis, ook van de (natuur)wetenschappelijke kennis voorbijgezien? Is hier niet al te vlot een scheiding gemaakt tussen geloofskennis en wetenschappelijke kennis?

Berkouwer het volkome reg as hy sê dat sowel die kennis van die algemene as die 
kennis van die besondere openbaring van God steeds geloofskennis is. Berkouwer mag egter hierdie geloofskennis nie teen die wetenskaplike kennis van die natuurwetenskap afspeel nie, want daarmee misken hy die belangrike (nie slegs Christelik-wysgerige nie, maar ook modern-sekulêr-wetenskapsteoretiese) insig dat alle wetenskaplike kennis gegrond is in geloofskennis. Deur dit in te sien, kan reg gedoen word aan die eenvoudige vasstelling dat God Hom enersyds geopenbaar het in die natuur en dat die natuurwetenskappe andersyds hulle met juis hierdie selfde natuur besighou. So kan die wetenskaplike ondersoek van die natuur wel deeglik gegrond wees in die geloofskennis van die algemene openbaring. Troost (1978:119) antwoord Berkouwer soos volg:

De schepselen, die, zij het nict onder het leidend gezichtspunt van bet geloof, maar onder dat van het theoretisch verdiepte denken, o.a. door de natuurwetenschappen onderzocht worden, geven toch in dat onderzock een deel van hun geheimen prijs aan de onderzoekers? De wetenschap brengt toch het resultaat van hun werk als geintendeerde (theoretische) waarheid naar buiten, en participeert ook de theoretische waarheid niet, naar haar structuur, in de volle Waarheid? En is de volle Waarhcid niet Christus, als het Woord Gods?

Hier dink Troost vanuit 'n radikaal-Christelike wetenskapsteorie, waarin argumente enersyds aangewend word om natuurwetenskap en geloofskennis van die natuur nie te vereenselwig nie en andersyds nie te skei nie, maar hulle samehang aan te toon en te analiseer. Hier word bowendien implisiet op die innerlike verband en die oorsprongseenheid van God se hele openbaring gewys - iets waarop Troost groot klem lê. Werken woordopenbaring is in werklikheid een, deurdat

* die hele skepping (God se werk) niks anders as die 'beliggaming' van God se Woord is, dit wil sê die ewige Woord van God kry binne die tyd deur Christus gestalte in die skepping van God; Christus is in persoon die Woord van God én die Wortel van die skepping. Die skeppingsopenbaring is dus self ten diepste woordopenbaring, naamlik openbaring van God se skeppingswoord in Christus.

- Andersyds is die Skrif, as die binne die tydelike skeppingswerklikheid gerealiseerde (op skrif gestelde) gestalte van die ongeskape, ewige Woord van God (vgl. Ouweneel, 1986:130-140), self ook 'n skepping van God in Christus. Die Skrif vorm binne die eenheid van God se skeppingsopenbaring die "uitstralend en richtingwijzend centrum van die openbaring" (Troost, 1978:121).

Die woordopenbaring is dus self feitlik skeppingsopenbaring, deurdat God se ewige Woord tot die mens kom in op skrif gestelde vorm in die gestalie van 'n goddelike skeppingswerk. Daardeur is daar, soos gesê (2.1.2), geen ruimte vir 'n prinsipiële 
verskil tussen die teologie en die ander vakwetenskappe in skolasties-dualistiese sin nie: die teologie is $606 \mathrm{k}$ gerig op God se skeppingsopenbaring (waarvan die Skrif die sentrum vorm), terwyl die ander vakwetenskappe ók gerig is op die Skrif (die 'soeklig' waarby die skeppingsopenbaring slegs werklik verstaan kan word). Woord- en werkopenbaring is een, soos ook God se woord en sy werk een is. ${ }^{4}$ Dit is die een (algemene) openbaring van God waarop alle vakwetenskappe ten diepste gerig is (realiter daar waar die wetenskaplike se hart in die greep is van die ewige Woord van God), al het elk van hulle sy eie modale gesigspunt van waaruit elk die skeppingswerklikheid besien.

In hierdie verband sou die vraag gestel kon word of Berkouwer bereid sou wees om dieselfde redenasie wat hy op die natuurwetenskappe toegepas het, mutatis mutandis ook op die teologie toe te pas met betrekking tot die 'besondere' openbaring. As hy die skolastiese dualisme tussen die teologie en die ander vakwetenskappe werklik radikaal afwys, moet hy myns insiens ook die volgende deur hom geïmpliseerde idees aanvaar (vergelyk hierdie punte een vir een met Berkouwer se betoog), naamlik

* dat ons die kennis van God se openbaring in die Skrif nie in hoofsaak te danke het aan die teologie nie, maar aan die kennis wat God deur sy Woord en Gees in die wedergebore hart werk;

- dat dit nie daarom gaan om die (teologiese) kennis van die Skrif sonder meer gelyk te stel met die (geloofs)kennis van God se besondere openbaring nie, want in hierdie openbaring gaan dit om kennis van God self en hierdie Godskennis ontstaan nie deur die teologie nie, maar deur die geloof;

- dat die teologie streng genome nie God se besondere openbaring 'ondersoek' nie, maar, soos gesê, die skeppingswerklikheid - die Bybel ingesluit - vanuit die geloofsgesigspunt;

- dat die stelling dat die teologie God se besondere openbaring 'ondersoek', 'n vervlakking van die begrip en die werklikheid van die openbaring impliseer, dit wil

\footnotetext{
${ }^{4}$ God se skeppingswoord is altyd aktueel (van Lat. actus, 'daad, handeling'), dit wil sê God se (skcppende en onderhoudende) woorde en (skeppende en onderhoudende) dade vloci hier in mekaar in. Dit stem ooreen met die feit dat die Hebreeuse רכר sowel 'woord' as 'saak' (soms in die betekenis 'daad') beteken. Ook kan die Griekse גoyos soms 'saak' met die betekenis 'daad' beteken (Hand. 8:21: 'werk'). Die onderskeid tussen woord- en werkopenbaring stuit reeds teen die feit dat die skerp onderskeid tussen woord en werk nie te handhaaf is nie. Vergelyk Troost (1978:122), wat verwys na G. von $\operatorname{Rad}(1960: 93$ c.v.).
} 
sê nie rekening hou met die teoreties-analitiese aard van teologiese kennis in onderskeiding van geloofskennis nie.

\title{
4.2 Wetenskap, wet en waarheid
}

Om in hierdie opsig die regte perspektief te kry en die natuurwetenskappe nie ondergeskik aan die teologie te maak nie (vanuit die skolastiese idee van die teologie as 'koningin' van die wetenskappe), is juis 'n radikaal-Christelike wetenskapsteorie so belangrik. Samevattend: ook die teologie besien, net soos enige vakwetenskap, sy ondersoekveld vanuit 'n bepaalde modale gesigspunt - in hierdie geval dié van die geloof (nie in sentraal-religieuse sin nie, maar in modaal-funksionele sin) - onder leiding van die teoreties verdiepte denke. Indirek is egter ook die teologie - net soos alle ander vakwetenskappe - wel deeglik betrokke by die Godsopenbaring, in dié sin dat die geïntendeerde (teoretiese) waarhede wat nagestreef word, volgens hulle struktuur deel het aan die volle Waarheid, dit is Christus as die Woord van God. Hier is, wat die betrokkenheid op die Godsopenbaring betref, geen prinsipiële verskil tussen die naturwetenskappe en die teologie en enige ander vakwetenskap aanwysbaar nie. Teoretiese waarheid is wel deeglik betrokke op die Godsopenbaring, maar altyd indirek; die geloofswaarheid oorstyg altyd die teoretiese waarheid, of dit nou teologiese of natuurwetenskaplike waarheid is.

Alle wetenskap is gerig op die sin-ontsluiting van die werklikheid, veral die ontsluiting van sy wetsy. Wetenskap is nie moontlik sonder die erkenning van hierdie wetsy nie. Ook die ongelowiges, wat nie die Wetgewer aanvaar nie, erken die bestaan van sy wette en gehoorsaam selfs noodwendig bepaalde wette en norme. 5 Soos Heyns (1978:9) sê:

\begin{abstract}
Iets van die bestaan van 'n God, van 'n rocping en 'n taak in hierdie wêreld, iets van die normatiwiteit van die logiese, juridiese, estetiese en etiese is aanwesig ook by hulle wat nic lewe uit die besondere openbaring nie. Die wat wél daaruit lewe, aanvaar dit as norme van God vir die mens. Aan die objektiewe evidensie van Gods ordeninge in en bepalinge vir die lewe en die klaarblyklike chaos waarin alles sal eindig indien dit nie gehoorsaam word nie, kan niemand ontkom nie,
\end{abstract}

ook al is daar by die ongelowige van 'n innerlike neiging en bereidheid van die hart om met liefde die wet van God te vervul, uiteraard geen sprake nie. Dit verander egter

5 Vgl. daaroor onder andere Hart (1984:25-28; by verwys na Hempel, Popper, Radnitzky, Stebbing en Toulmin) en Stafleu (1987:240; hy verwys na Bunge en Popper). 
niks aan die feit dat die ongelowige in sy gewone lewe en in sy wetenskapsbeoefening nie anders kan as om die wet te erken nie. Daardeur bly sy arbeid buite sy wil om altyd georiënteer op die Wetgewer.

In die reformatoriese denke is hierdie siening op die perseptiviese konvergensie en integrasie van alle waarhede in Hom wat die Waarheid is, van essensiële belang. Nóg natuurwetenskaplike nóg teologiese nóg geesteswetenskaplike waarhede fungeer ooit as op-sigself-staande waarheidsfragmente. Dit is slegs die geval in 'n onjuiste teorie oor wetenskaplike waarheid, waarin die waarheidsidee - soos Troost dit uitdruk innerlik gebroke en gedisintegreerd is. Hierdie fragmentariese waarheidsidee is gegrond op 'n fragmentaristiese siening van die werklikheid, waarin die Christelike skeppingsbelydenis nie alleen nie meer funksioneer nie, maar vervang is deur ' $n$ humanistiese werklikheidsidee (Troost, 1969:20). En hierdie siening moet dan aan die gangbare natuurwetenskap sy waarheidsgehalte verleen! Hierdie (volkome gesekulariseerde) natuurwetenskap het nog slegs 'n baie afstandelike verband tot die Waarheid. In soverre as hierdie siening nog 'waarheidsfragmente' bevat, is dit meer ondanks as danksy hierdie siening.

Op hierdie punt stuit ons betoog teen die vraag of en in watter sin en mate wetenskaplike teorieë 'waarheid' oplewer omtrent die skeppingswerklikheid. In watter $\sin$ is wetenskap gerig op ontsluiting van die kosmiese wetsorde en onthul dit daarmee iets omtrent die Wetgewer? Slegs enkele punte word aangestip:

- Alle wetenskaplike navorsing gaan noodwendig uit van die ontologiese aksioma dat 'n objektiewe wetsorde bestaan, en dat die hoofdoel van hierdie navorsing die ontdekking van objektiewe ordeninge en dus die ontsluiting van die wetsorde is. Wetenskap is nie 'n orde-skeppende aktiwiteit nie, maar 'n orde-ontsluitende aktiwiteit.

- Die aanvaarding van die bestaan van 'n objektiewe wetsorde is nie ' $n$ vakwetenskaplike saak nie, maar 'n wysgerige saak; die transendentaal-wysgerige ondersoek na die moontlikhede en grense van die wetenskaplike kenne 'raak' aan hierdie wetsorde en vorm daarvan 'n wysgerige idee (nie begrip nie).

- Die aanvaarding van die bestaan van 'n wetsorde én die (h)erkenning daarvan as skeppingsorde, dit wil sê die (h)erkenning dat die wetsorde verwys na 'n Skepper en Wetgewer, is nie 'n bloot wysgerige saak nie, maar berus op 'n voorteoretiese geloof van sentraal-religieuse aard en inhoud, gegrond in die selfopenbaring van die Skepper. 
- Ware wetenskap is moontlik wanneer die verstand en waarneming van die mens (aan die feitelike sy van die werklikheid) aan die Skrif onderworpe is asook aan die wetsorde wat die Skepper ingestel het en waarop verstand en waarneming hulle rig om die struktuurwette waaraan die kenobjek onderworpe is, te ontdek. Hierdie onderworpenheid aan die Skrif en aan die wetsorde maak ook die mens se rasionele en perseptiewe funksionering moontlik. Wetenskapsbeoefening geskied dan ook in (bewuste of onbewuste) onderwerping van die ken-aktiwiteit aan die kennorme wat eweneens deur God in die skeppingsorde ingestel is, soos hul in die logika en die kennisteorie gepositiveer (moet) word.

- Die wetenskap, wat gerig is op die ontdekking van die wette, probeer om hierdie wette vas te lê in formuleringe (teorieë) wat nie ontdek nie, maar uitgevind word. Teorieë (66k teoretiese teorieë) word nie afgelei uit die feite nie, maar uitgevind om die feite te verklaar; hulle word nie aan ons opgelê dér die werklikheid nie, maar deur ons opgele áán die werklikheid. Daarom, hoewel die objektiewe wette (aan die wetsy) konstant is, verander die subjektiewe (d.i. aan die ken-subjek eie) wetenskaplike teorieë (aan die feitelike sy) voortdurend.

Wetenskaplike teorieë poog om waarheid te verwerf, maar sodanige waarheid impliseer altyd tegelyk betreklike (want veranderlike) waarheid. Ook vorm wetenskaplike teoriee spesialistiese waarheid (want dit betrek slegs 'n gespesialiseerde aspek van die praktiese lewenservaring); en deel-waarheid, want daar is naas teoretiese (logies-analitiese) waarheid ook nie-teoretiese waarheid soos sosiale, ekonomiese, estetiese, juridiese, etiese en geloofswaarheid. ${ }^{6}$

- Ware kennis van die wetsorde gaan nie op in een van die werklikheid se modale aspekte of selfs in sy integrale modale sin-samehang nie. Die wetsorde kan slegs verstaan word in 'n bo-teoretiese en bo-modale idee (nie begrip nie) van die volheid, eenheid en oorsprong van hierdie wetsorde. Hierdie idee is self slegs weer moontlik vanuit die sentraal-religieuse kennis van die Waarheid in die gelowige hart, in onderworpenheid aan die Godsopenbaring in Christus en in die Skrifte en deur die krag van die Heilige Gees.

\footnotetext{
${ }^{6}$ In dic sin van pisties gekwalifiseerde waarheid ('dit is seker! betroubaar!'), well te onderskei van geloof in sentraal-religieuse sin.
} 


\section{Bibliografie}

BAVINCK, H. 1928. Gereformeerde dogmatiek. Kampen : Kok.

BERKOUWER, G.C. 1951. De algemene openbaring. Kampen : Kok.

DENGERINK, J.D. 1986. De zin van de werkelijkheid. Amsterdam : VU Uitgeverij.

HART, H. 1984. Understanding our world : An integral ontology. Lanham : University Press of America.

HEYNS, JA. 1978. Dogmatiek. Pretoria : NG Kerkbockhandel.

HEYNS, J.A. \& JONKER, W.D. 1977. Op weg met die teologie. Pretoria : NG Kerkboekhandel.

JONKER, W.D. s.j. Die brief aan die Romeine. Kaapstad/Pretoria : NG Kerk-Uitgewers.

KöNIG, A. 1982. Teologie. (In Eybers, J.H., König, A. \& Stoop, J.A. red. Inleiding in die teologie. Pretoria : NG Kerkboekhandel. p. 1-44.)

KUYPER, A. 1908/09. Encyclopaedie der beilige godgeleerdheid, dl. I, II. Kampen : Kok.

OUWENEEL, WJ. 1986. Woord en wetenschap. Amsterdam : Buijten \& Schipperheijn.

SMIT, J.H. 1980. Skeppingsopenbaring en wetenskap. Tydskrif vir Christelike Wetenskap, 16:174-200.

STAFLEU, M.D. 1987. Theories at work. Lanharn : University Press of America.

STRAUSS, D.F.M. 1978. Inleiding tot die Kosmologie. Bloemfontein : Sacum Beperk.

STRAUSS, D.F.M. 1988. Begripsvorming in die sistematiese teologie. Tydskrif vir Christelike Wetenskap, 24:124-161.

TROOST, A. 1969. De openbaring Gods en de maatschappelijke orde. Philosophia Reformata, 34:1-37.

TROOST, A. 1978. De relatie tussen scheppingsopenbaring en woordopenbaring. Philosophia Reformato, 43:101-129.

VANDER STELT, J.C. 1978. Philosophy and Scripture. Martton (NJ.) : Mack Publ. Comp.

VON RAD, G. 1960. Theologie des Alten Testaments, Bd. II. München : Kaiser Verlag. 